\title{
ПРОБЛЕМА ЗДОРОВ'ЯЗБЕРЕЖЕННЯ В ІСТОРІЇ РОЗВИТКУ ПЕДАГОГІЧНОЇ ДУМКИ
}

Кучерган С. В. Проблема здоров'язбереження в історії розвитку педагогічної думки.

У статті проаналізовано історію розвитку проблеми здоров'язбереження в педагогіці та висвітлено процеси якісного розвитку поняття здоров'я в педагогічній думці різних часів. Висвітлено особливості здоров'язбереження як частини педагогічної ідеології суспільства. Розкрито фундаментальні підвалини історичного досвіду здоров'язберігальних технологій в освітніх процесах різних суспільних формацій. Визначено провідні тенденції становлення вітчизняної системи освіти в поєднанні зі змінами в розумінні ролі педагога в здоров'язбережувальних процесах.

Ключові слова: здоров'я, здоров'язбереження, педагогічна думка, здоров'язберігальні технології, особистість, гармонійний розвиток, життєдіяльність людини.

Кучерган Е. В. Проблема сохранения здоровья в истории развития педагогической мысли.

В статье проанализированы история развития проблемы здоровьесбережения в педагогической мысли и освещены процессы качественного развития здоровья в педагогической мысли разных времен. Освещены особенности здоровьесбережения как части педагогической идеологии общества. Раскрыты фундаментальные основы исторического опыта здоровьесберегающих технологий в образовательных процессах различных формаций построения общества. Определены ведущие тенденции развития, становления отечественной системы образования в объединении с изменениями в понимании роли педагога в процессах сохранения здоровья.

Ключевые слова: здоровье, здоровьесбережение, педагогическая мысль, здоровьесберегающие технологии, личность, гармоническое развитие, жизнедеятельность человека.

Kuchurgan Ye. V. The problem of health preservation in the history of educational thought.

The article analyses the history of problems of health preservation. The purpose of the article is to show the development of health preservation in different historical period of educational thought formation. Features of health preservation as part of the educational thought of society are highlighted. Fundamental bases of historical experience of healthy technology in educational processes of various public formations are revealed. Leading tendencies of a national education system combined with changes in understanding of a role of the teacher in processes of health preservation have been defined. At civilized approach the main function of health preservation is an active resistance to influence of hostile environment, such as the human person and society. Training of students in safety measures of existence in hostile environment is the main component of health preservation in pedagogics; where continuous improvement of school and university education is basic. A general education where the leading role is given to the teacher who owns humanistic pedagogics of the self-identification based on the principles: nature correspondence and culture correspondence has to be applied. The philosophical fundamentals of the harmonious development of personality and her life are examined. The dynamics of disease overcoming as a process of scientific work is shown.

It has been proved that Ukraininan National Pedagogical School of health preservation has to be grounded on a study of a history of people at school and educational system which corresponds the traditions. Based on the historical development of the nation, children should be linked to their land and their native culture, and participate in creating the image of the ideal human being as a citizen of Ukraine.

Key words: health, health preservation, pedagogical idea of healthy technology, personality, 
harmonious development, human activity.

Проблема полягає в погіршенні здоров'я всіх учасників навчально-виховного процесу. Створюється загрозлива ситуація в забезпеченні життєдіяльності їхньої особистості, яка в основному пов'язана з освітніми процесами. Тому цілком зрозуміло, що здоров'язбереження в навчально-виховному процесі впродовж усієї історії розвитку педагогічної думки привертає велику увагу теоретиків і практиків вищої педагогічної освіти.

В історії педагогіки питання здоров'язбереження в освітньому процесі розглядали Д. Латишина, М. Левківський, О. Піскунов, В. Торосян, М. Мазалова, Т. Уракова та ін. Саме роботи «Історія освіти і педагогічна думка», «Історія педагогіки», «Історія педагогіки та освіти» висвітлюють здобутки світової думки в педагогіці з позицій соціокультурного підходу. Історія становлення освітньої галузі вперше розкрита з урахуванням впливів побуту і звичаїв народу, як система педагогіки здоров'язбереження, навчання та виховання дитини.

Відповідно до теми нашої публікації найбільш продуктивною вважаємо історичну періодизацію педагогічної думки, запропоновану О. Антоновою, яка в педагогіці визначає три періоди розвитку:

I період - донауковий - до XVII століття;

II період - концептуальний - XVII - XIX століття (створення окремих теоретичних концепцій виховання та освіти);

III період - системний - кінець XIX століття - до наших днів (становлення педагогіки здоров'язбереження як наукової системи) [1].

Основна проблема покращення здоров'я всіх учасників освітнього процесу може бути розв'язана застосуванням здоров'язберігальних технологій студентів - майбутніх учителів різного профілю,- які б сформували програму практичних дій, що гарантувала б високий рівень гармонійного розвитку особистості на всіх етапах і напрямках їі розвитку.

На різних етапах історичного розвитку всіма науковцями-педагогами порушувалося питання здоров'язбереження учня і вчителя в педагогічному процесі. На сьогодні цю тему досліджують такі науковці, як: О. Джуринський, О. Піскунов, М. Левківський, С. Сисоєва, якими було встановлено проблеми здоров'язбереження в педагогічній думці виховних процесів освітньої галузі.

Mema cmammi - висвітлити проблеми генезису здоров'язбереження в різні історичні періоди становлення педагогічної думки, а також відстежити закономірності розвитку та систематизації проблем здоров'язбереження в становленні педагогічної освіти.

Висвітлення проблем здоров'язбереження в педагогічній думці розпочинається 3 донаукового періоду, де первісна людина, намагаючись вижити в агресивному природному оточенні, зазнавала утисків та травм. Надаючи собі примітивну медичну допомогу випадковими діями на рівні буденної свідомості, згодом вона вдосконалювала та застосовувала свій досвід у стосунках з іншими людьми. Набір рішень первинної допомоги 3 розвитком суспільства трансформуються в систему охорони здоров'я [2]. При цьому людина природно прагнула зберегти своє фізичне здоров'я. Накопичення та передача досвіду збереження здоров'я згодом знаходить своє місце в педагогіці. Елементарні засоби захисту від несприятливих зовнішніх умов - холоду, негоди, прикриття тіла або окремих його частин одежею, влаштування примітивних осель, хоча б самого лише даху - все це примітивні зачатки гігієни [3].

3 появою сім'ї як соціального інституту зароджується духовне здоров'я. Сімейне виховання породжує народну педагогіку, яка поглиблює принципи морального здоров'я. У первісному суспільстві розподіл їжі був за принципом обсягу праці. Згодом почали застосовувати педагогічні впливи на особистість, які виробляли в неї відповідні звички допомагати хворим і слабким, віддавати кращу їжу їм.

Сімейне виховання поглиблює статеве розмежування: жінки виховують дівчаток як майбутніх матерів, а чоловіки хлопчиків за трьома ідеалами - вождя, жерця, старійшини, що зумовило спеціалізацію здоров'язбереження за ідеалом вождя, який орієнтував розвиток 
особистості на фізичну підготовку до війни і керівництва общиною. За ідеалом жерця в розвитку особистості надавалась перевага інтелекту, оскільки така особа у своїй діяльності виконувала релігійні обряди й ритуали. Найбільша частина первісного суспільства готувалася до праці. Тому можемо стверджувати, що здоров’я людини в суспільстві набуло фізичних, інтелектуальних і моральних форм розвитку [19].

При становленні державності на Давньому Сході, а саме Єгипті, Межиріччі, Китаї та Індії, розвиток пріоритетів здоров'язбеження переходить на рівень державності. У спеціальних виховних закладах - школах, накопичення та примноження інформації було процесом трудомістким, що потребувало фізичного здоров'я, оскільки для стимуляції учнів застосовувалось покарання [7].

Особливості здоров'язбереження в державах Стародавньої Греції полягали в розмежуванні поглядів на виховання: спартанського й афінського. Спартанці склали систему на основі фізичного виховання та військової справи під повним контролем держави. Афінська ж система виховання прагнула до гармонійної особистості - науковця, у якій намагались поєднати на основі фізичного розвитку мораль, розум та естетику - ідеальної людини. Тому той, хто прекрасний тілом і душею, відповідає ідеальному здоров'ю.

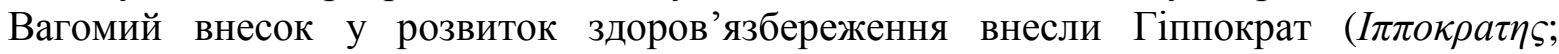

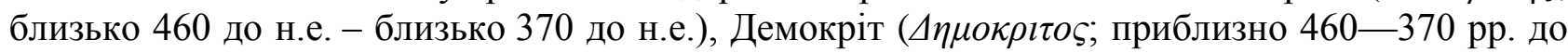

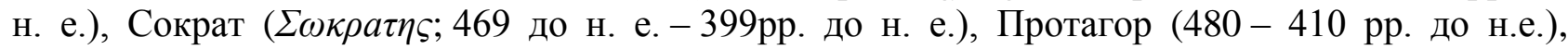

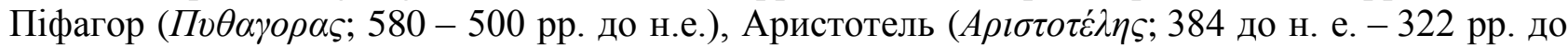

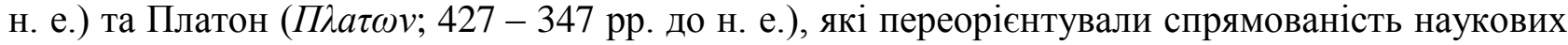
інтересів на вивчення проблем організації життєдіяльності як умови задоволення соціальних та етичних потреб особистості. Також убачали розвиток особистості в гармонізації взаємозв’язку фізичного тіла та системи мислення, iї емоційних станів, бажань, почуттів, що складають світ розуму духовного та матеріального початків у досягненні досконалості здоров'я [14].

У добу Середньовіччя посилюється спеціалізація освітніх процесів, а значить удосконалюється система здоров'язбереження, яка розвивається за напрямами: церковне виховання на практиці заперечувало мирські втіхи для більшого посилення моральних якостей; лицарське виховання передбачало панування над землею та селянами, що розділяло суспільство на дві категорії: «вища» - у якій збереження здоров’я полягало в презирливому ставленні до всіх видів праці, навіть до інтелектуальної і віддавалась перевага тільки фізичним, військовим справам; та «нижчу» 3 кріпосницькою мораллю [6].

Доба Відродження - це формування нового гуманістичного погляду на світ та життя людини. Гуманістичні погляди здоров'язбереження формувалися в запереченні середньовічного аскетизму, поставивши в центр уваги здорову людину без відхилень, перебільшень і ії гармонійний розвиток. На цих ідеях починає вибудовуватись і гуманістична педагогіка, яка піддає різкій критиці середньовічне схоластичне виховання, що не спроможне забезпечити нормальний життєдіяльний розвиток людини, яка в ідеалі радіє життю, сильна духом і тілом, має повне право на земні та духовні радості i їх збалансованість у вигляді сформованості високих моральних якостей.

Педагоги-гуманісти Еразм Роттердамський (Desiderius Erasmus Roterodamus; 14661536 pp.), Франсуа Рабле (François Rabelais; 1494-1553рp.), Мішель де Монтень (Michelde Montaigne; 1553-1592 рр.), в Англії Томас Mop (Sir Thomas More; 1478-1535 рр.), в Італії Томазо Кампанелла (Tommaso Campanella; 1568-1639 pp.), Вітторінода Фельтре (Vittorino da Feltre; 1378-1446 pp.) по-новому розуміли мету і завдання виховання. Вони бачили нормальний розвиток дитини та їі здоров'я в гармонізації суспільства й особистості учня шляхом гармонізації почуттів, поваги до дитячої особистості, заперечували сувору дисципліну та тілесні покарання. Вони визнавали за необхідність ураховувати особливості дитячого віку, індивідуалізувати навчання і виховання для покращення здоров'я дитини, різко критикуючи середньовічну схоластичну систему виховання і навчання, яка цього не передбачала. Вони протиставили ій таку систему виховання, яка гармонізувала, тобто 
ідеально узгоджувала фізичні, інтелектуальні, моральні цінності і розвивала здорову людину - розумово і фізично, формуючи в неї високі моральні якості [4].

Вершиною, завершенням донаукового періоду є педагогічна система Я. Коменського (Jan Amos Komensky;1592-1670рр.), який розвивав загальне бачення світу i, переборюючи недосконалість, склав власну педагогічну філософію, що надала можливість у подальшому обгрунтувати весь комплекс педагогічних питань і визначити педагогіку як науку. Шкільна освіта, за Я. Коменським, повинна бути універсальною: «у школах потрібно вчити всіх усьому..., але від учнів не вимагати знання всіх наук і мистецтв, адже це безглуздо і за малою тривалістю нашого життя неможливо, а навіть шкідливо для здоров'я у всіх відношеннях. Учитель повинен навчати учнів прагнути розпізнавати основи, властивості і цілі всього найважливішого, що існує і розвивається, щоб у цьому світі не зустріти нічого, про що б вони (учні) не могли скласти бодай скромного судження». Запобігання таких перевантажень, за концепцією здоров'язбереження, визначається як система поглядів на сутність педагогічної діяльності, іiї мету, завдання, об’єкт і суб'єкт діяльності, способи та засоби ії здійснення тощо, яка, у процесі усунення внутрішніх або зовнішніх суперечностей, самоорганізовується, гармонізується й забезпечує самозбереження й саморозвиток [12].

Джон Локк (John Locke;1632-1704pp.) у своїй педагогічній концепції проблему здоров'язбереження вбачає в нездоровому суспільстві та його нездоровому впливі на особистість. Оздоровлення суспільства науковець убачає тільки через систему освіти та виховання [15].

Здоров'язбереження під час французького Просвітництва пов'язане з такими іменами, як Шарль Луї де Монтеск'є (Charles-Louis deSecondat, Baronde La Bredeet de Montesquieu; 1689-1755 pр.), Вольтер (Voltaire; 1694-1778 pp.), Жан-Жак Руссо (Jean-Jacques Rousseau; 1712-1778 pр.), Дені Дідро (Denis Diderot; 1713-1784 pp.), Поль Анрі Гольбах (Paul Heinrich Dietrich Baronvon Holbach; 1723-1789 pp.), Гельвецій (Claude Adrien Helvetius; 17151771 рр.), Етьєн Бонно де Кондільяк (Etienne Bonnotde Condillac; 1714-1780 pp.), Жульєн Oфре де Ламетрі (Julien Offray de La Mettrie; 1709-1751 pp.), Йоганн Генріх Песталоцці (Johann Heinrich Pestalozzi; 1746-1827рр.) та ін. Просвітителі боролися за оздоровлення суспільства, але ненасильницькими методами. Вони стверджували, що світом правлять ідеї, тому суспільству для оздоровлення потрібно змінити ідею негативну на позитивну через освіту [3].

Між педагогами філантропістами та неогуманістами можна виділити Базедова Йоганна-Генриха-Бернгарда (Johann Bernhard Basedow; 1724-1790рр.) як засновника цієї течії в педагогіці, а також Іоахіма Генриха Кампе (Joachim Heinrich Campe;1746- 1818 pp.), Вільгельма фон Гумбольдта (Friedrich Wilhelm Christian Karl Ferdinand Freiherrvon Humboldt; 1767-1835 рр.), Фрідріха Августа Вольфа (Friedrich August Wolf; 1759-1824 рр.), ЙоганнаГоттфріда Геердера (Johann Gottfried Herder;1744-1803 pp.) та ін. Вони намагались реалізовувати здоров'язбереження учнів через механізми любові до людини, їх шкільні заклади створювались серед розкішної природи за принципом «природа, школа, життя». У своїх педагогічних теоріях філантропісти виходили 3 того, що покращення умов життя людей неможливе без покращення навчально-виховної роботи в освітніх закладах. Основною метою було готувати люблячих життя людей, які б займались удосконаленням систем фізичного, інтелектуального та духовного виховання. Вони, як педагоги, заклали низку педагогічних ідей, які мали важливе продовження: шкільна гімнастика, трудове навчання, дитяча література, педагогічна освіта та ін. [1].

Німецька філософія I. Канта (Immanuel Kant; 1724-1804 pp.), Г. Гегеля (Georg Wilhelm Friedrich Hegel; 1770-1831 pp.), А. Дистервега (Friedrich Adolph Wilhelm Diesterweg; 1790 1866 pр.), Й. Гербарта (Johann Friedrich Herbart; 1776-1841рр.), обгрунтувала на основі ідеї гуманістичної самосвідомості особистості шляхи реформування шкільної та університетської освіти. Адольф Дістервег (Friedrich Adolph Wilhelm Diesterweg; 1790-1866 рр.) приділяв велику увагу оздоровленню освіти через загальнолюдське виховання, у якому керівну роль відводив учителю. Він уважав, що в людей за допомогою системи виховання потрібно 
розвивати схильності єдиної любові до людства, а особливо до свого народу. Основною метою виховання він вбачав гармонізацію всіх задатків людини, які вона повинна спрямовувати для служіння істині, красі й добру. Ідеальна гармонія виховання повинна базуватися на трьох принципах: природовідповідності, культуровідповідності та самодіяльності. Спираючись на ці принципи, в подальшому Дістервег створив «дидактику розвиваючого навчання» [11]. Йоганн Фрідріх Гербарт (Johann Friedrich Herbart; 1776-1841рр.) був прихильником асоціативної науково-психологічної педагогіки. Велику увагу він приділяв мінливостям у процесі розвитку особистості, які впливали на утворення морального характеру. В основі цього характеру, уважав він, лежать особливості тіла, тому в інтересах морального виховання потрібно займатись здоров'язбереженням. Гербарт, як i більшість педагогічних мислителів, здоров'язбереження розуміє як систему такого способу життя, який загартовує тіло: «Я схвалюю все, що загартовує тіло, і переконаний, що надалі знайдуть такі способи загартування людини, які будуть зміцнювати їі дух у цілому за власною ініціативою і нададуть їй можливість реалізовувати свою діяльність у відповідних напрямках, а також відчувати гордість у власних очах» [17]. Фребель Фрідрих Вільгельм (Friedrich Frobel; 1782-1852 pp.) німецький педагог, який створив ідею «дитячого садка». Процеси здоров'язбереження дітей дошкільного віку вбачав у створенні спеціальних дитячих закладів (садків) і організації такої ігрової діяльності, яка повинна розвивати у дітей природну рухливість, безпосередність характеру, а також неабияку допитливість, прагнення до здорових форм наслідування та вільної творчості [9].

Реформаторська педагогіка розглядала процеси здоров'язбереження під кутом педагогіки «вільного виховання», що бере за основу вільне виховання всупереч системі погроз. Її представниками є Кей Еленн Кароліна Софія (Ellen Karolina Sofia Key 18491926 рр.), Генріх Шаррельман (Genrih Sharrelman;1871-1940 pp.), Марія Монтессорі (Maria Montessori; 1870-1952рp.), за поглядами яких, дітей не потрібно виховувати спеціально, а необхідно надати можливість дитині самостійно розвиватись і стати сонцем, навколо якого обертаються всі виховні процеси. Перед школою постає завдання здоров'язбереження дитини через розвиток творчих сил за допомогою дитячої фантазії. На думку Марії Монтессорі, школа повинна бути лабораторією, де вивчаються психологічні особливості дітей та проводяться систематично антропологічні обстеження [5].

Наступним кроком психолого-педагогічної науки була експериментальна педагогіка, або педологія, заснована на освітніх поглядах медичної домінанти в освітній галузі. Представниками цього напрямку були Лай Вильгельм Август (Wilhelm August Lay; 18621926 рр.), «Школа дії» Ернст Мейман (Ernst Friedrich Wilhelm Meumann;1862-1915 pp.), у Франції - Альфред Біне (Alfred Binet;1857-1911 pp.), у США - Едвард Лі Торндайк (Edward Lee Thorndike; 1874-1949 pp.), які намагалися завдяки останнім дослідженням в галузі психології визначити, наскільки можливо точно організувати педагогічні впливи на особистість учня. Експериментальна педагогіка здоров'язбереження намагається бути інтеграційною наукою, синтезуючи в собі педагогіку, фізіологію та психологію. Здоров'язбереження полягало у визначенні можливостей кожної дитини і завдяки цьому в конкретизації розвитку кожного за допомогою індивідуально розробленої програми навчання та виховання. В основі програми був інтелектуальний розвиток дитини. Експериментатори вважали, що попередня педагогіка мала абстрактний характер нормування, тому для більш наукового обгрунтування педагогічних процесів і самої педагогіки потрібно більш поглиблене обстеження дитини. Вони вказували на необхідність синтезованого знання про дитину, яке базується на анатомії та фізіології, а також на психології та патопсихології. Головним способом дослідження були визначені випробування тестами, на основі яких педагоги намагались відшукати засоби, за допомогою яких здійснювали навчання учнів ефективними методами [16].

Педагогіка прагматизму, в основу якої покладена дія у прагненні до істинного, що приносить користь. Представником цієї педагогіки був Джон Дьюї (John Dewey; 18591952 рр.), за концепцією якого виховання повинно розвиватись не на основі спадковості, а за 
власним досвідом дитини. Дж. Дьюї намагався оздоровити суспільство, примиривши різні класові групи, увівши виховання на основі трудового навчання. При тому він уважав, що трудове навчання $є$ елементом загальної педагогіки, а не професійної. У зв'язку з тим, що саме ручна праця $є$ основою проходження дитини через усі етапи еволюції, що пройшла людина [18].

У педагогіці «громадянського виховання» i «трудової школи» Георг Міхаель Кершенштейнер (Georg Michael Kerschensteiner; 1854-1932 pp.) вбачав соціальне здоров'язбереження народної молоді, щоб діти не зазнали згубного впливу вулиці їх необхідно зробити трудовою молоддю за допомогою трудової школи. Потрібно завоювати владу над їхніми думками, а також серцем, щоб у подальшому вони стали повноцінними громадянами своєї країни. Для цього їм потрібно дати максимум практичних навичок у професійній підготовці. Теоретичні знання сприймаються як супроводжувальний процес для посилення професійності.

Нові школи за теорією «нового» виховання повинні забезпечувати розвиток дітей, які повинні бути готовими виконувати свої суспільні обов'язки на основі гармонійного i природного виховання. Яскравим представником був Адольф Фер'єр (Adolphe Ferriere;18791960 рр.), який організовував школи інтернатного типу, де створене штучне середовище складалось 3: 1) мальовничих природних місць; 2) енциклопедичних знань учнів; 3) вільних і активних методів навчання; 4) високого матеріального забезпечення; 5) шкільного самоврядування. Ці всі умови і повинні забезпечити фізичний, розумовий та моральний розвиток дітей, пристосованих до практичного життя [14].

Педагоги етико-гуманістичного напрямку, представниками якої були на Україні Г. Сковорода (1722-1794рр.), І. Котляревський $\quad$ (1769-1838рр.), Т. Шевченко (18141861 рр.), П. Куліш (1819-1897 рр.), О. Духнович (1803-1865 рр.), уважали, що через поширення освіти можливо народ зробити щасливим. У центрі їх ідей здоров'язбереження були взаємини людини і природи. Вони пропагували, що зміст і суть людини залежить «від сродної праці», тобто людина щаслива тоді, коли вона відповідає своєму призначенню. Вони були прихильниками організації народної школи, в основі виховання якої була сім'я, і батько та мати були зразком, живими іконами. Метою ж такої освіти в кінцевому результаті розвитку особистості є гармонізація розумового, фізичного, морального й естетичного виховання. Фізичне виховання повинно починатись до народження і полягало в здоровому способі життя батьків. Турбота родини про майбутніх своїх дітей повинна була починатись 3 турботи про матір. Розумове здоров'я розумілося як здатність пізнавати добро і зло. Все виховання переважно покладалося на вчителя, тому його постать піддавалась нищівній критиці і побажанням бачити народного вчителя здоровим, привітним, з гнучким мисленням. Педагоги мріяли про власну систему викладання й українські підручники [11].

Видатний український педагог К. Ушинський (1824-1870рр.) першим у педагогіці піднімав питання про оздоровлення народу як фундаментальної основи оздоровлення держави, він говорив, що «народ $\epsilon$ єдиним джерелом історичного життя держави i найкрасивішим створінням божим на землі». Ці погляди геніального науковця доводили те, що фізичне, духовне й соціальне здоров'язбереження людини полягає у формуванні здорового покоління. У поколінні, яке повинно поважати свій народ та примножувати його як фізичне, так і духовне здоров'я. Усе це можливе тільки при створенні своєї держави, для чого повинна існувати народна педагогіка. Так, народна мудрість для К. Ушинського була тими підвалинами, на яких повинна розбудовуватися в своєму змісті вся педагогічна, державна система. Він у своїх трактатах довів, що в основі здорових змістів наукової педагогіки повинна бути закладена мораль народної педагогіки.

Педагогічна система здоров'язбереження К. Ушинського вбирала в себе намагання зробити педагогічну систему наукою на основі народності. Він постійно заявляв, що головним рушієм прогресу в суспільстві й історичним розвитком суспільства $є$ наука та освіта на основі народної творчості. Тому педагогічна наука повинна бути більш практичною і прикладною, теоретичний розвиток повинен мати також практичне пристосування у вигляді порад для 
батьків і вчителів. Принципи народності виховання К. Ушинський розглядає, як право кожного народу на самовизначення, оскільки самобутність кожного народу коріниться передовсім у характері кожного індивіда. Саме виховання визначається самою сутністю особистості людини; саме характер є та сутність, за якою фундаментом є народність [10].

Неабияку роль у розвитку здоров'язбереження педагогічної думки в Україні на зламі XIX і XX століть відіграли відомі діячі освіти, представники педагогіки просвітительськодемократичного напряму: М. Пирогов (1810-1881 рр.), М. Корф (1834-1883 рр.), Х. Алчевська (1841-1920 рр.), Ю. Федькович (1834-1888 рр.), Б. Грінченко (1863-1910 рр.), М. Коцюбинський (1864-1913рp.), І. Франко (1856- 1916 рр.), Леся Українка (Лариса Петрівна Косач-Квітка) (1871-1913 рр.), Т. Лубенець (1855-1936 рр.). Ця система мала характер загальнолюдського виховання і заперечувала вузько спрямоване навчання, але у випадках оздоровлення за умови помірного або незадовільного здоров'я для широкого навчання можливі варіанти звуженої спеціалізації. М. Пирогов стверджував, що професійна освіта за всіма канонами повинна передовсім вибудовуватись на основі загальної освіти, а вже потім відбуватись спеціалізація за профільними предметами. Він боровся за самостійність університетів та реформування освіти, яка повинна виховувати особистість громадян: «Усі хто бажає бути патріотом і громадянином своєї держави повинен спочатку навчитися бути особистістю». Педагоги просвітительсько-демократичного напряму вважали, що основне завдання педагогіки здоров'язбеження- це підготовка людей-громадян із широким світоглядом і високими гуманними почуттями. Основними засобами просвіти повинні бути навчання грамоти та ведення бесід повчального характеру [10].

Організація здоров'язбереження нації в основному була спрямована на охорону фізичного здоров'я. Недостачу морального та соціального здоров'я в педагогіці намагались компенсувати - I. Стешенко (1873-1918 рр.), М. Грушевський (1866-1934 рр.), П. Блонський (1884-1941 pp.) та С. Русова (1856-1940 рр.), які, здійснюючи організацію системи освіти в Україні, намагалися, щоб в іiі основі лежала українізація. Вони накреслили програму становлення національної освіти в Україні.

Особливого значення оздоровленню нації через освіту надавав М. Грушевський (1866-1934рр.), його думка полягала в системо-творенні української школи. Займаючись розвитком і творенням української історії, він, застосовуючи історичний метод, уважав, що основою здорової нації є іï історія. Тому докладав багато зусиль для поширення історичних знань серед народу, вивчення історії у школах та створення педагогічної системи на основі історичного становлення нації. Порушення радянською владою історичного минулого українського народу повинне бути виправлене діяльністю суспільних організацій. Він залюбки пропагував українську історію в Парижі, Петербурзі. Видавав підручники для вивчення історії українського народу. Розробив проект створення Української Академії Наук. Він обгрунтував створення Українських кафедр при університетах [8].

Великий внесок в розвиток гуманістичного підходу до виховання особистості було зроблено А. Макаренком (1888-1939 рр.), Г. Ващенко (1878-1967 рр.) та В. Сухомлинським $(1918$ - 1970 рр.). Їхні праці $є$ базовими основами гуманістичного виховання сучасної особистості. Концептуальні основи їхніх педагогічних систем зберігають актуальність донині. Педагогічна система А. Макаренка була запропонована як практична наука, яку можливо закріпити, використовуючи метод соціально-психологічних установок на формування дитячого колективу. Установка негативного катарсису (нитиків та панікерів), які сіють песимізм складає першу загрозу духовності. А. Макаренко стверджував, що «не існує окремо колективу вчителів та вихованців». Катарсичність ідеї А. Макаренка полягає в тому, що корекція відбувається тоді, коли особистість повинна досягти рівня духовності i здібностей усього колективу. Саме в цьому особистісному перетворенні індивід починає бути носієм колективних здібностей і можливостей, у цьому й полягає духовний катарсис особистості. Чим більший колектив, уважав А. Макаренко, тим більші його можливості. Колективне життя складає колективістську свідомість. У єдиному колективі вихователям легше виховувати, а в дітей швидше відбувається соціалізація, іншими словами 
дорослішання [13].

Система Г. Ващенка полягає у створенні образу виховного ідеалу української людини. Здоров'я цього ідеалу побудоване на двох головних принципах: перший - християнської моралі і другий- української духовності, що спрямовані на службу Богові і Україні. Християнська мораль ставить основу виховання загальнолюдських цінностей: закон творення добра і боротьби зі злом, шукання правди і побудова справедливого суспільства, що спирається на закони краси і любові. Продовжуючи систему катарсисного виховання через колектив, Г. Ващенко поширює іiї за межі держави на рівень національної діяльності. Педагог-гуманіст мріяв про оздоровлення нації через систему виховання [9].

Система особистісно зорієнтованого підходу $\quad$ В. Сухомлинського полягає в багатоаспектній ідеї всебічного розвитку особистості, іiі пронизує проблема проектування людини. Здоров'я розвитку особистості складається з розумового, морального, естетичного, трудового та фізичного. При недостатній несформованості одного із названих компонентів говорити про нормальний розвиток немає сенсу. Варто говорити про порушення i неможливість розв'язати жодне педагогічне завдання. За цією теорією, виховна робота спрямовується на те, щоб дитині дати відчуття повноти життя за моральними канонами. Провідне місце в цій виховній системі займає розвиток творчого початку. Особливо В. Сухомлинський приділяв велику увагу загальному зміцненню здоров'я, успіх у навчанні визначається турботою про те, як спить, як харчується дитина, яке іiї загальне почуття, як вона грає, який режим дня, наскільки часто вона буває на свіжому повітрі. На його думку, дитина краще мислить на природі, саме там потрібно ставити запитання. Діти повинні жити в світі краси, а спільні переживання на природі дають вчителю можливість працювати творчо разом 3 дитиною. Виховання естетичних та етичних цінностей на природі розкривають у вихованцях все найкраще [10].

Історія розвитку педагогічної думки достатньо виразно демонструє проблеми збереження здоров'я. За весь час розвитку цивілізації в системі освіти мали місце різні цілі та технології здоров'язбереження людства. У різні часи ці технології мали різне ідеологічне та педагогічне підгрунтя і з розвитком суспільства вдосконалювались, накопичуючи досвід здоров'язбереження, спрямований на гармонізацію взаємовідносин 3 зовнішнім середовищем, розвиток та вдосконалення соціальних відношень у побудові державності. Основний напрямок здоров'язбереження - це гармонізація розвитку особистості, а перетворення універсально історичного досвіду технологій здоров'язбереження в педагогічній думці повинно суттєво покращити практикум здоров'я та життєдіяльність учасників педагогічного процесу.

\section{Література}

1. Адаменко О. Особливості і тенденції розвитку педагогічної науки в Україні у другій половині XX століття / О. Адаменко, В. Курило // Рідна школа. - 2012. - № 4/5. С. 39-43. 2. Алексєєв В. П. Історія первісного суспільства / В. П. Алексєєв, А. І. Першиц // Наука. - 1990. - C. 6-16. 3. Галузинський В. М. Педагогіка: теорія та історія / В. М. Галузинський, М. Б. Євтух. - Київ : Вища школа, 1995. - 237 с. 4. Джуринский А.Н. История педагогики / А. Н. Джуринский. - Москва : Гуманит. изд. центр ВЛАДОС, 2000. 432 с. 5. Завгородня Т. К. Історія педагогіки: [навчально-методичний посібник] / Т. К. Завгородня, Л. М. Прокопів, І. В. Стражнікова. - Івано-Франківськ, 2014. - 160 с. 6. Історія педагогіки / за ред. М. С. Гриценка. - Київ : Вища школа, 1973. - 447 с. 7. Кравець В. П. Історія класичної зарубіжної педагогіки та шкільництва / В. П. Кравець. Тернопіль : Тернопіль,1996. - 436 с. 8. Латышина Д. И. История педагогики, история образования и педагогической мысли / Д. И. Латышина. - Москва : Гардарики, 2005. - 603 с. 9. Левківський М. В. Історія педагогіки / М.В.Левківський. - Київ : Центр навчальної літератури, 2011. - 190 с. 10. Лузан П. Г. Історія педагогіки та освіти в Україні : [навчальний посібник] / П. Г. Лузан, О. В. Васюк. - [2-ге вид., доп. і перероб.]. - Київ : ДАКККіМ, 2010. 296 с. 11. Любар О. О. Історія української школи i педагогіки / О.О. Любар, М. Г. Стельмахович, Д. Т. Федоренко. - Київ: Знання, 2003. - 450 с. 12. Мазалова М. 
История педагогики и образования [Електронний ресурс] / М. Мазалова. - Режим доступу: http://royallib.com/book/mazalova_marina/istoriya_pedagogiki_i_obrazovaniya.html.

13. Максимюк С. П. Педагогіка: [навчальний посібник] / С. П. Максимюк. - Київ : Кондор, 2005. - 667 с. 14. Мешко О. I. Історія зарубіжної школи і педагогіки / О. І. Мешко, О. І. Янкович, Г. М. Мешко. - Тернопіль : ТДПУ, 1996. - 207 с. 15. Пискунов А. История педагогіки / А. Пискунов. - Москва : ТЦ «Сфера», 1998. - 304 с. 16. Попов В. А. История педагогики и образования / В. А. Попов; под ред. В. А. Сластенина. - Москва : Издательский центр «Академия», 2012. - 208 с. 17. Пряникова В. Г. История образования и педагогической мысли: [учебник-справочник] / В. Г. Пряникова, 3. И. Равкин.- Москва : Новая школа, 1995. - 96 с. 18. Степашко Л. А. Философия и историяобразования / Л. А. Степашко. - Москва : Московский психолого-социальный институт: Флинта, 1999. 272 c. 19. Фіцула М. М. Педагогіка / $\quad$ М. М. Фіцула. - Київ : Академія, 2001. $-527 \mathrm{c}$.

УДК 371.12

Володимир Марків

\section{ПЕДАГОГІЧНА ДІЯЛЬНІСТЬ НАРОДНИХ ШКІЛ ПІВДЕННО-СХІДНОЇ УКРАЇНИ У ХІХ СТОЛІТТІ (ІСТОРИКО-ПЕДАГОГІЧНИЙ АСПЕКТ)}

Марків В.М. Педагогічна діяльність народних шкіл Південно-Східної України у XIX столітті (історико-педагогічний аспект).

У статті розглядається питання формування вчительського персоналу в XIX столітті для початкових класів. Історичний контекст становить XVIII - на початку XIX століття, коли відбувається активний процес колонізації Північного Причорномор'я (побудова нові міст Херсона, Миколаєва, Одеси, великої кількості містечок і сіл; розвиток промисловості, торгівлі, суднобудування, сільське господарства; виникнення і функціонування перших осередків освіти - народних шкіл, актуалізація питання щодо їх кадрового складу).

Ключові слова: народні школи, кадровий склад, ланки освіти, осередки освіти, учительські кадри, педагогічні знання, підготовка вчителів, професійний педагог, початкова школа.

Маркив В. Н. Педагогическая деятельность народных школ Юго-Восточной Украины в XIX веке (историко-педагогический аспект).

В статье рассматривается вопрос формирования учительского персонала в XIX веке для начальных классов. Исторический контекст составляет XVIII - нач. XIX века, когда происходит активный процесс колонизации Северного Причерноморья (построение новые городов - Херсона, Николаева, Одессы, большого количества городов и сел, развитие промышленности, торговли, судостроения, сельское хозяйства, возникновение и функционирование первых очагов образования - народных школ, актуализация вопроса их кадрового состава).

Ключевые слова: народные школы, кадровый состав, звенья образования, ячейки образования, учительские кадры, педагогические знания, подготовка учителей, профессиональный педагог, начальная школа.

Markiv V. N. Educational activity of folk schools in the south-east of Ukraine in XIX century.

In XIX century there was a sharp contradiction between a demand for well-educated and prepared production workers and extraordinarily low level and backwardness from the modern requirements of all branches of education in the Russian empire of that time. The position of affairs in Ukraine were considerably worse, than in the central provinces of Russia. The imperial power, trying to retain people in obedience, used school for this purpose. The Russian-language studying made difficulties in understanding of learning material by Ukrainian-speaking children. Church 